Article

\title{
Opportunities and Challenges of Companies from the Romanian E-Commerce Market for Sustainable Competitiveness
}

\author{
Camelia-Daniela Hategan ${ }^{1}$ (D), Ruxandra-Ioana Pitorac ${ }^{2, *(\mathbb{D})}$, Vasile-Petru Hategan ${ }^{3}$ (i) \\ and Carmen Mihaela Imbrescu ${ }^{1}$ \\ 1 Department of Accounting and Audit, Faculty of Economics and Business Administration, \\ West University of Timisoara, 300115 Timisoara, Romania; camelia.hategan@e-uvt.ro (C.-D.H.); \\ carmen.imbrescu@e-uvt.ro (C.M.I.) \\ 2 Department of Economics and Economic Modeling, West University of Timisoara, 300115 Timisoara, Romania \\ 3 Institute of Media and Social-Humanitarian Sciences, South Ural State University, \\ 454080 Chelyabinsk, Russia; vphategan@gmail.com \\ * Correspondence: ruxandra.pitorac@e-uvt.ro
}

\section{check for} updates

Citation: Hategan, C.-D.; Pitorac, R.-I.; Hategan, V.-P.; Imbrescu, C.M. Opportunities and Challenges of Companies from the Romanian E-Commerce Market for Sustainable Competitiveness. Sustainability 2021, 13, 13358. https://doi.org/10.3390/ su132313358

Academic Editors: Katarzyna Cheba, Iwona Bąk and Katarzyna

Szopik-Depczyńska

Received: 2 November 2021

Accepted: 30 November 2021

Published: 2 December 2021

Publisher's Note: MDPI stays neutral with regard to jurisdictional claims in published maps and institutional affiliations.

Copyright: (c) 2021 by the authors. Licensee MDPI, Basel, Switzerland. This article is an open access article distributed under the terms and conditions of the Creative Commons Attribution (CC BY) license (https:/ / creativecommons.org/licenses/by/ $4.0 /)$.

\begin{abstract}
Consumer behavior differs from country to country, which may implicitly influence the financial performance of e-commerce companies. The paper's objective is to study the characteristics of the companies from the Romanian e-commerce market for sustainable competitiveness. The empirical analysis was a quantitative and qualitative one. For the qualitative analysis of the studied sample, variables that represent the specific characteristics of companies were taken into account, the most relevant of which will be included as control variables in econometric models. Research results highlight that the recognized companies registered lower values of financial performance, they influence each other and for the company to improve the customer relationship, they have to invest in brand consolidation. The practical implications can be for managers to focus on companies' branding, improving customer relations, disclosing more information about the company, the products they sell online, and sustainability actions to have sustainable competitiveness.
\end{abstract}

Keywords: e-commerce; market share; growth; financial performance; sustainable competitiveness

\section{Introduction}

According to Eurostat data [1], in 2019, the penetration rate of e-commerce in European Union countries was on average more than $60 \%$, the highest rate was recorded by the Nordic countries of about $80 \%$, and the lowest was in Bulgaria (22\%) and Romania (23\%). Although, the internet has a penetration rate of $73.8 \%$ in Romania, above the world average, below the average of $85.2 \%$ of European Union countries, the penetration rate of e-commerce has been low. Regarding the share of e-commerce in a country's GDP, the situation is different. The highest was in the United Kingdom at almost $8 \%$ and the lowest of less than $2 \%$, in several European countries, Romania having a share of $2.4 \%$ GDP, which denotes a different behavior of consumers from one country to another [2].

Online commerce facilitates the purchase of goods from abroad, so that, on average $44 \%$ of EU citizens bought goods from abroad, generally from neighboring countries. The share of those who bought goods from sellers in the origin's country was $86 \%$, with maximum values of $95 \%$ in the Netherlands, and lower in Latvia (65\%) and Croatia (67\%). In Romania, the share of local products was high, at 93\% [2].

These differences between countries show a distinct consumer behavior from one country to another, which can implicitly influence the financial performance of e-commerce companies. To strengthen its position on the market, building a favorable image of the company by using branding as a long-term investment can contribute to the return on shareholder investment. E-commerce reveals opportunities to accelerate consumer knowledge 
about brands engaged with the sustainable competition due to stakeholder expectations, compared to classic commerce, traditionally focused on competitiveness or sustainability.

In the last three decades, much research has addressed different aspects of brand equity, outlining two points of view: financial and perceptual [3]. The topic of brand equity has been widely debated in definitions, models, and the identification of indicators for measuring them by various methods. Brand equity is defined as a success factor that differentiates each company in its relationship with its competitors in the market. The similarity between the economic significance of brand equity and the customer-based brand equity (CBBE) significance is that both come from a marketing decision context [4]. The CBBE concept was developed by Aaker [5,6] and Keller [7,8], who stated that CBBE has several components based on customer perception of companies, which generate consumer behavior as a result of branding.

In general, brands with high levels of equity are associated with outstanding performance, such as high market shares and successful expansion into new businesses, competitive cost structures and high profitability, which contribute to the competitive advantage of companies [8]. Creating a recognized brand has benefits for both the company and consumers. The main benefit is that it increases consumer confidence and reduces their risk regarding the products purchased. From the company's point of view, branding should contribute to higher profit margins, increase the company's value, increase stock market shares and improve financial performance. Previous research $[3,8]$ has focused more on companies with recognized brands and less on local brands. This fact draws our attention to the gap in previous studies, so the purpose of this study is to fill the gap, to highlight whether branding can lead to better financial performance.

Given the importance of this topic, the paper's objective is to study the characteristics of companies from the Romanian e-commerce market for sustainable competitiveness in terms of brand consolidation. We decided to focus our research on Romanian companies because the internet has had a higher penetration rate in the last years. According to Eurostat [9], only $23 \%$ of Romania's population made online purchases in 2019, which shows that Romanian e-commerce has significant growth potential.

The methodology applied for the empirical analysis consists of a panel data econometric models using two-stage least squares (2SLS) regression and instrumental variables (IV) to estimate the correlations between the following indicators: recognize brand (RB), age of the company (A), number of employees (E), growth rate of revenue (GR), e-commerce categories (EC), physical stores (S), information about company on website (I), RO brand $(B)$, market share (MS), return on equity (ROE), return on assets (ROA) and net profit margin (NPM).

The originality of the research consists of a comprehensive study of Romanian companies' brand and financial performance in the e-commerce market. Secondly, the variables included in the econometric model were selected to reproduce the characteristics of the analyzed companies as accurately as possible. The study will contribute to the literature by analyzing companies' characteristics of the Romanian e-commerce market for sustainable competitiveness, especially for small companies with exclusive online commerce activity.

The remaining paper is structured as follows: a review of the specialized literature is made in the second section, followed by the explication of the methods and methodology applied, the results obtained, and a discussion. The last section includes the conclusions, limitations, and future research directions.

\section{Literature Review}

Companies operating in e-commerce have marketing approaches in which communication is based on words, used in the form of a communication vector, and which are based on a simple principle, derived from Wittgenstein's philosophy, expressed in the famous Tractatus Logico-Philosophicus, in which he emphasized that everything that can be said in words can be said in short $[10,11]$. It is the essential principle that has been taken over by those working in the field of transmitting the message of promoting an organization, 
applied in the form of marketing message or company image, included in the branding concept to generate consumer confidence and build a strong reputation in the competitive market. As a philosopher of language, Wittgenstein expressly referred to the relationship between seller and buyer by the remaining rhetorical question, noting that, "Someone divides human beings into buyers and sellers, and forgets that buyers are sellers as well. If I remind him of this, is his grammar changed?" [12].

The image and the word expressed in a promotional message, are the main elements that can attract consumers to buy or learn about a particular market, and the online environment is largely oriented towards this form of promoting and supporting a business. Some authors liken this approach to a form of communication of a mystical nature, becoming a religion of communication, in which the product is the one that attracts the consumer, like the church that attracts a particular type of person [13]. One of the initiators of language pragmatics is Austin, who is concerned with identifying forms of language application in a form as applied as possible. One of his works entitled How to Do Things with Words [11,14], may be an excellent support to those who work on forming the image and message of promoting a business or product.

Of course, to influence the consumer's behavior, the product supplier needs to gain his trust and to build a reputation that supports it. In this sense we consider it essential that the promotional message considers the need to present the product as accurate as possible, by including conditions of sincerity, as they were developed by the American philosopher Searle [11,15], who continues the investigation into the philosophy begun by Austin. This aspect can be found on most electronic platforms, including review sections on their product and service, including critical ones. To present the opinions of consumers who use this type of trade as accurately as possible, there is a presentation and identification section of the company that owns the online store is necessary. This fact contributes to strengthening consumer confidence in using the services offered by the developed platform, specific to this type of trade.

The reputation thus gained can be strengthened by using the concept of relational marketing, in which a satisfied consumer will make direct or indirect recommendations on his experience, and the first beneficiaries of this experience are the people he interacts with, either in the family or in social media in which it is connected. In the same context, the relational approach can be taken over by the company holding the e-commerce platform, which becomes concerned with applying relational design elements, [16] derived from the ontological approach of the concept, being studied in the context of technology introduction and globalization.

Popa et al. [17] analyzed the effect of e-business on the performance of financial firms in the specific context of small and medium-sized manufacturing enterprises (SMEs) in Spain, and the results showed that e-business had a direct effect on financial performance and was positively associated with organizational innovation.

From the Flash Eurobarometer 439 Survey in 2017 on 863 companies, Šaković-Jovanović et al. [18] found that the effect of e-commerce on enterprise performance is not direct and needs to be examined using several mediating factors. The results showed that, the relationship between e-commerce and sales performance is generally negative, but the benefits of e-commerce to increase sales were more evident when companies used commercial sites and online marketplaces.

The e-commerce sector links digitalization to transition to a more sustainable economy. The growth of e-commerce should be seen as an opportunity to move from a classic retail trade to a more sustainable one as well as an opportunity to use digitalization for this purpose. Investigating the effect of e-commerce on the performance of small and mediumsized enterprises (SMEs) based on a questionnaire addressed to SMEs managers in Iran, Sedighi and Sirang [19] showed that the use of e-commerce was statistically significant for variables such as financial performance, internal process, customers, growth and learning.

The impact of using online marketing tools on a company's performance was examined by Orzan et al. [20], based on a questionnaire addressed to Romanian companies in 
the textile industry (production, distribution, or retail) and found that online marketing had a positive impact on organizational performance.

The best-known authors who have published research on the concept of brand equity are Aaker and Keller, who have published individual and joint papers. From their point of view, the brand is considered an intangible asset that must be measured, for which they have proposed several indicators.

Aaker's [5] brand equity model contains five elements: brand loyalty, brand awareness, brand quality, brand association, and brand assets. He considered that brand awareness is an essential element of brand equity, defined as "the ability of the potential buyer to recognize and recall that a brand is a member of a certain product category".

According to Keller's [7] conception, the components of brand equity are salience, performance, imagery, judgments, feelings, and resonance. Keller considered that brand equity could be likened to a pyramid built on four levels, based on salience and reaches the top of resonance, to create a harmonious relationship between brand and customer.

Brand equity can be evaluated from many perspectives. Christodoulides and Chernatony [21] reviewed the literature on conceptualizing and measuring consumer-based brand equity, grouping them into direct and indirect methods. Farjam and Hongyi [22] reviewed over 60 brand equity studies, chronologically analyzing the evolution of the literature on the concept of brand equity from the views expressed by Aaker and Keller to the definition given by Clow and Baack [23]. They considered that the brand's equity is a set of features that make it a unique brand in the market, allowing the company to charge a higher price and maintain a higher market share than would be possible with an unbranded product brand. The study's conclusion by Farjam and Hongyi [22] consisted of the fact that brand equity was discussed from three different perspectives: financial, customer and employee.

Investigating 200 top UK marketers and CFOs on measures to increase the return on investment of marketing, Ambler [24] found that "awareness" and "market share" were the most widely used measures by respondees, while "loyalty/retention" and "relatively perceived quality" were the most appreciated.

Brand equity is different from brand value because it is not an exclusively financial measure but a way to calculate the reputable asset that a successful business builds psychologically in the customers' mind. Kovachevski et al. [25] conducted a comparative analysis of the top 10 globally ranked brands in 2018 based on four different brand value methodologies in published reports of research organizations in the field (BrandZ, Interbrand, Brand Finance Global and Forbes). The results showed that they were concentrated in the United States, and in the first place were companies in technology and electronic commerce. On the other hand, Chinese brands had the most significance increases in brand value compared to the previous year.

Christodoulides et al. [26] concluded that the unique characteristics of the Internet make consumers co-creators of brand value which is an essential source of online competitive advantage. Thus, they found that the brand equity of online retail and service was correlated with the emotional connection, the online experience, the receptive service, trust, and fulfillment.

Several studies have tested the links between brand equity and its components and firm value, failing to provide a direction with similar results [27-31]. Thus Johansson et al. [29] found that the intensity of the relationship between brand equity and financial performance differs depending on the measure applied and how each capture equity.

Choi et al. [32] examined the factors that lead to the sustainable performance of ecommerce enterprises in Vietnam, namely whether the quality characteristics of e-services positively influence on customer loyalty, which is one of the sustainable success factors of e-commerce to promote electronic trust as a vital element.

The relationship between CBBE and market share by different brand types (global versus local) across different groups of countries (developed versus emerging) was examined by Zarantonello et al. [33], based on a survey of consumer goods from 29 countries. The 
study results showed that the relationship between CBBE components and market share was stronger for local brands than global ones, and in emerging countries, the relationship between each CBBE component and market share was stronger for global brands than local ones.

Analyzing the relationship of financial variables and brand equity to provide a helpful perspective on management, Smith et al. [34] found a significant positive correlation between brand equity and gross profit, advertising expenses, and research and development expenses. Isberg and Pitta [35] described a method of quantitative valuation of brand equity using financial analysis techniques focused on return on equity (ROE) and return on assets (ROA) on Safeway Company (an American supermarket) and concluded that the most effective strategy is to develop the brand by concentrating on consumer preferences.

Examining the relationship between brand equity and financial performance based on a questionnaire applied to 550 customers of 28 banks operating in Ghana as of June 2015, Narteh [31] found that the quality of services, brand association, brand loyalty, and brand relevance have positively and significantly influenced the financial performance of retail banks. While Schmitz and Roman [36] showed that the brand's equity is associated with financial performance even in companies that are not listed and do not have globally recognized brands, through the association between brands and performance based on financial accounting indicators.

Wang and Sengupta [37] investigated the links between stakeholder relations, brand equity, and firm performance on a sample of 81 multinational companies in the period 2005-2008. The results indicated that brand equity mediates the link between stakeholder relationships and firm performance.

The ultimate goal of marketing business strategies is to create a long-term relationship with customers. A vital marketing strategy of e-commerce companies is the designing of websites to effectively develop and improve relationships with customers [38]. The evolution of technologies requires companies to have more up-to-date strategies to understand customers, involve them in collaboration through different media channels, create value for brand recognition [39] and retain the customers [40]. Other previous studies have analyzed the digitization and e-commerce of SMEs [41,42] in different sectors [43] and territories [44].

For an e-commerce company to create a sustainable competitive advantage, its brand must be well differentiated from that of other competing companies [45], which involves adopting strategies for development in terms of sustainable competitiveness [46]. Consumer loyalty could be one of the main factors in strengthening market competitiveness and strengthening the sustainable competitive advantage [47]. Other determinants of online shopping behavior that could have an impact on the strategic management process in the competitiveness of e-commerce can be website design, the intensity of interactive communication with the customer and the credibility of the e-store [48].

As the business grows, e-commerce can contribute to sustainability, through which companies will not only make economic gains, but will also contribute to environmental and social issues [49]. Thus, the promotion of ethical behavior belongs to the organizational philosophy of each company [50].

According to Cheba et al. [51], sustainable competitiveness has two main components: "sustainable competitive capacity and sustainable competitive position". These components are measured by indicators calculated at a national level and reveal the level of development. Their study concluded that Romania had improved the level of sustainable competitiveness in the last years, having previously ranked lower in their capability to compete sustainably in the field of the environment [52].

\section{Materials and Methods}

To achieve the proposed objective, to study the characteristics of the companies from the Romanian e-commerce market, we selected the relevant non-financial and financial indicators based on the availability of data and the literature. The empirical research was quantitative and qualitative. For the qualitative analysis of the studied sample, variables 
that represent the specific characteristics of companies were taken into account, the most relevant of which will be included as control variables in econometric models. The quantitative analysis consisted of a panel data econometric model using a two-stage least squares (2SLS) regression.

For the non-financial indicators, the selected variables are: recognized brand (RB), age of the company (A), the number of employees (E), growth rate of revenue (GR), ecommerce categories (EC), physical stores (S), information about company on website (I), $\mathrm{RO}$ brand (B) and market share (MS). The indicator recognized brand was taken from the Statista database, and it is a dummy variable with the value 1 if the companies are included on ranking and value 0 if the companies are not included. This database contains all relevant online stores in a country, ranked based on sales and brand awareness. Thus, we considered that the inclusion of companies in this database was more relevant than the results obtained based on questionnaires conducted on a sample of respondents.

The financial indicators, from the previous research [53-55] concluded that the most used indicators are the ones that express the financial performance: return on equity (ROE), return on assets (ROA), and net profit margin (NPM).

Keller [8] considered that companies whose brands have generated a high level of customer awareness increased financial results. Managers evaluate through indicated marketing strategies such as the rate of revenue growth [35], market share, profitability, and brand value. From the previous research, market share was a utilized indicator in brand evaluation $[8,25]$ therefore, we analyzed it in our empirical research.

The description of the analyzed indicators is presented in Table 1.

Table 1. Description of the variables

\begin{tabular}{|c|c|c|c|}
\hline Variables & Code & Description & Source \\
\hline \multicolumn{4}{|c|}{ Dependent variables } \\
\hline Return on equity & ROE & Net income/shareholders equity & Financial statements 2019 \\
\hline Return on assets & ROA & Net income/assets & Financial statements 2019 \\
\hline Net profit margin & NPM & Net income/revenue & Financial statements 2019 \\
\hline \multicolumn{4}{|c|}{ Endogenous variable } \\
\hline Recognize brand & RB & $\begin{array}{l}\text { 1-If the company is included on ranking from } \\
\text { ecommercedb.com } \\
\text { 0-If the company is not included on ranking from } \\
\text { ecommercedb.com }\end{array}$ & $\begin{array}{c}\text { Statista ecommerceDB.com } \\
\text { (accessed on } 10 \text { February 2021) }\end{array}$ \\
\hline \multicolumn{4}{|c|}{ Independent variables } \\
\hline Company age & A & No of years of function & Financial statements 2019 \\
\hline Employees & $\mathrm{E}$ & Ln of average number of employees & Financial statements 2019 \\
\hline \multicolumn{4}{|c|}{ Instrumental variables } \\
\hline Growth rate of revenue & GR & Growth rate of revenue $2019 / 2018$ & Financial statements 2019 \\
\hline E-commerce categories & $\mathrm{EC}$ & 1 to 5 according to the methodology & Statista ecommerceDB.com \\
\hline Physical stores & $\mathrm{S}$ & $\begin{array}{l}1-\text { Yes } \\
0-\text { No }\end{array}$ & Website of companies \\
\hline Information about company on website & $\mathrm{I}$ & $\begin{array}{l}1-\text { Yes } \\
0-\mathrm{No}\end{array}$ & Website of companies \\
\hline RO brand & B & $\begin{array}{c}\text { 1-Romanian } \\
\text { 0-Other }\end{array}$ & Website of companies \\
\hline Market share & MS & Market share of online commerce of company in 2019 & Own computation from websites \\
\hline \multicolumn{4}{|c|}{ Company Characteristics } \\
\hline Development region & $\mathrm{R}$ & 1 to 8 according to the NUTS of Romania & Financial statements 2019 \\
\hline Activity field & $\mathrm{AC}$ & NACE codes & Financial statements 2019 \\
\hline
\end{tabular}

Source: Authors' own work.

Launching an online store does not always lead to better financial performance, as there is high competition in the e-commerce market [56]. Given that it takes a while for the online store to be known, we chose the age variable to be tested in the proposed model $[36,57,58]$. Additionally, the number of employees shows the company's size, and they are essential resources for the success of the company's brand [22,59]. 
For the construction of the variable information about the company on the site, three elements were considered: if the company publishes the information regarding its legal status, if it has carried out sustainability actions and if it sells "green" products. If at least two elements were identified, the score was 1 , otherwise 0 .

The data were collected from Statista ecommercedb.com and the financial reports published on datagov.ro. In Romania in 2019, approximately 25,000 companies were registered with trade activity, of which $80 \%$ were active. Of these, $37 \%$ were active in the retail sector. Of the retail companies, only $2 \%$ had the main activity of online commerce. All the others traded in physical stores as their primary activity, but they also had online stores. In Romania there is no obligation for companies to report the revenues obtained by activities separately. All current public information is only estimated by official institutions and national and international organizations that monitor specific areas, such as online commerce.

The studied sample consisted of companies with online commerce activity, on websites addressed to Romanian clients, based in Romania with revenues of more than EUR 1 million in 2019 and with at least two years of experience. For the sample to be representative, we selected the companies according to the turnover, the number of employees, seniority, and the declared trade activity so that all companies had a high probability of being included in the sample.

The companies were divided into two groups depending on the degree of brand recognition of the online store. The first group (group 1) consisted of companies with a recognized brand on the Romanian market, included in "Top 100 Online Stores in Romania by Revenue" by Statista ecommercedb.com. The second group (group 2) consisted of companies that were not included in the list mentioned above and had declared their main activity NACE code 4791—retail sale via mail order houses or via the Internet. Initially, 73 companies were identified in the first group, and 146 were identified in the second group. After the preliminary analysis of the indicators, the companies that registered losses were eliminated so that the final sample included 65 companies in group 1 and 119 companies in group 2, so a total of 184 companies were included in the final sample. Companies with losses were eliminated because the loss distorts profitability ratios; some companies also had negative equity, which led mathematically to positive ROE (which is a significant distortion).

According to the Statista ecommercedb.com methodology [60], the revenues obtained by online stores are grouped into five categories: (1) electronics and media (EM), (2) fashion (F), (3) food and personal care (FPC), (4) furniture and appliances (FA), (5) toys, hobbies, and DIY (THD).

Previous research investigated the hypothesis that firms that invest in brand recognition will benefit from better performance $[36,57,58]$. Because the financial indicators and brand recognition influence each other, we have endogenous variables that could lead to inconclusive and inconsistent relationship findings [61-63]. In this case a proper methodology is recommended using the instrumental variables (IV) to counter the endogeneity issues. Previous research has found that instrumental variables are difficult to define in terms of strength and validity [64], but we identified several relevant IV for our objective.

Using a two-stage least squares (2SLS) regression, we tested three models in which the dependent variables $(\mathrm{Y})$ were: return on equity (ROE), return on Assets (ROA) and net profit margin (NPM). For all models, the independent variables were age of the company (A) and number of employees (E); the endogenous variable was recognize brand (RB) and the instrumental variables were growth rate of revenue (GR), e-commerce categories (C), physical stores (S), information about company on website (I), RO brand (B) and market share (MS).

The analyzed models have the following form:

$$
\begin{gathered}
Y_{i}=\alpha_{i}+\beta_{1} A_{i}+\beta_{2} E_{i}+\beta_{3} R B_{i}+\varepsilon_{i} \\
R B_{i}=\alpha_{i}+\beta_{1} G_{i}+\beta_{2} E_{i}+\beta_{3} S_{i}+\beta_{4} I_{i}+\beta_{5} B_{i}+\beta_{6} M_{i}+\varepsilon_{i}
\end{gathered}
$$


To validate the econometric model, we first performed an OLS regression and an ANOVA test. Afterwards we used the Doornik-Hansen test to check for multivariate normality and the Lawley test to check for symmetric correlations between variables. The multicollinearity was tested using variance inflation factor (VIF) and the endogeneity with Durbin-Wu-Hausman test. A two-stage least squares (2SLS) regression was chosen due to the endogeneity of the variables. To check the robustness of the model and the validity of overidentifying structural restrictions, we performed the Sargan and Basmann chi-squared tests. All the tests and estimations were performed in Stata Statistical Software: release 14.1.

\section{Results}

The characteristics of the companies grouped in the two groups: RB companies and non-RB companies, are presented in Table 2.

Table 2. The characteristics of the companies.

\begin{tabular}{ccc}
\hline Companies' Characteristics & RB & Non-RB \\
\hline Predominant development region & $77 \%$ Bucharest Ilfov & $59 \%$ Bucharest Ilfov \\
Age & 14.2 & 8.6 \\
Predominant NACE code & $477^{*}$ & $479 *$ \\
Predominant e-commerce category & Fashion & Furniture and appliances \\
Average number of employees & 1144 & 18 \\
Romanian brand & $57 \%$ & $99 \%$ \\
Physical store & $72 \%$ & $34 \%$ \\
Information about companies & $94 \%$ & $71 \%$ \\
\hline * 477 Retail sale of other goods in specialized stores; ** 479 Retail trade not in stores, stalls or markets. \\
Source: Authors' own work.
\end{tabular}

RB companies represent a third of the analyzed sample. If we analyze by the value of sales, the online stores that hold the largest share are the RB stores, which obtained $75 \%$ of companies' total revenues included in the sample. The highest revenues were obtained by the stores in the EM category, and the lowest by those in THD. Out of the total of the analyzed companies, over $80 \%$ registered increases in revenues in 2019 compared to 2018; the share is similar in both groups. The most significant increase in sales was almost $400 \%$, recorded by a non-RB company with sales in the EM category, and the most significant decrease was recorded in a non-RB company with sales in the FA category.

The largest market share was of the emag.ro store owned by the company Dante International S.A. (with majority foreign shareholders) with a share of $27 \%$ in total ecommerce sales, but with a market share of $85 \%$ of total sales in the EM category, which means that it has a dominant position on the Romanian market. The next place was occupied by dedeman.ro owned by Dedeman S.r.l., a company with Romanian partners considered the most successful business in Romania, with a total market share of $3.6 \%$ and $20 \%$, respectively, in the FA category. The next is altex.ro owned by Altex Romania S.r.l., a company with Romanian owners, which registered a share of 3.3\% in total e-commerce sales, with a total market share of $15 \%$ in the FA category. The three companies at the top of the ranking are Romanian brands that have become known to consumers over 15 years.

In the category of non-RB companies, the highest market share of $1.29 \%$ was registered by an e-store that sold products from the EM category.

In Romania, there are 8 development regions, of which the most developed region is Bucharest-Ilfov, which means that there are significant regional disparities from an economic point of view [65]. The data suggest that 77\% of RB companies are headquartered in this region, while non-RB companies are more territorially dispersed, the percentage decreasing to $59 \%$. Regarding the number of years from the establishment, the RB companies have a higher age of 14.2 years compared to 8.6 years of the others, which would mean that it takes a longer period until the position of a company is consolidated on the market.

Retail companies can carry out their activities through physical or online stores, meaning they must legally declare their main activity according to NACE codes. It is observed that RB companies are predominantly NACE code 477 , which means that it is 
possible that most of the revenue was obtained from sales in physical stores. If the volume of online sales exceeded that of physical stores, the change produced should not be declared in the financial statements.

It was found that most online stores (over $80 \%$ ) were specialized in one product category, but there were also department stores that sold products in several categories (4 categories-5\%, 3 categories-5\%, 2 categories-9\%). The data analysis showed that most online stores sold products predominantly from the FA category $(24 \%)$, followed by those from the FPC category (22\%), and in last place were the stores with products from the THD category (14\%). If we analyze the two groups, it turned out that most online RB stores sold products in the fashion (F) category (35\%), and those with non-RB are online stores that sold products in the FA category $(29 \%)$.

The number of employees had an average value of 416 employees, from 1 (for one company) to 10,761. From the average number of employees in the two groups of companies, the average is 1144 for RB companies and 18 for non-RB. This indicator confirms that most non-RB companies are SMEs.

Of the RB companies, $57 \%$ were online stores with Romanian brands (the best known being emag.ro), while among those in the non-RB group, the percentage was $99 \%$, which means that Romanian companies still have a lot to invest in becoming a recognized brand. Physical stores and showrooms are essential for customers because they can see and try the products before buying them, so $72 \%$ of RB companies had physical stores while non-RB only $34 \%$, so it can be said that their existence can positively influence brand recognition.

The voluntary disclosure of information on the online store website must be as complete and transparent as possible so that information about the seller, and sustainability can be essential for the performance of companies. Therefore $94 \%$ of RB companies posted this information compared to $74 \%$ non-RB.

The empirical research continued with the descriptive statistics of the analyzed indicators, presented in Table 3, from which it can be observed that from 35\% of the RB companies the average growth rate of all companies was $34.15 \%$, and the market share of online commerce of the companies in 2019 was an average of $0.46 \%$, varying from $0.05 \%$ to $26.98 \%$. Regarding the financial performance of the companies, they register, on average, a return on equity of $47.16 \%$, and the net profit margin was, on average, $7.11 \%$.

Table 3. Descriptive statistics.

\begin{tabular}{cccccc}
\hline Variables & Obs & Mean & Std. Dev. & Min & Max \\
\hline Dependent variables & & & & \\
\hline Return on equity (ROE) & 184 & 47.1605 & 30.360 & 0.537 & 146.89 \\
Return on assets (ROA) & 184 & 19.746 & 16.294 & 0.208 & 78.27 \\
Net profit margin (NPM) & 184 & 7.1151 & 6.0956 & 0.0429 & 37.716 \\
\hline Endogenous variable & & & & \\
\hline Recognize brand (RB) & 184 & 0.3567 & 0.4792 & 0 & 1 \\
\hline Independent variables & & & & & \\
\hline Company age (A) & 184 & 10.603 & 5.9533 & 2 & 28 \\
Employees (E) & 184 & 416.335 & 1493.081 & 1 & 10769 \\
\hline Instrumental variables & & & & & \\
\hline Growth rate of revenue (GR) & 184 & 34.1511 & 51.132 & -27.02 & 397.99 \\
E-commerce categories (EC) & 184 & 2.9297 & 1.3271 & 1 & 5 \\
Physical stores (S) & 184 & 0.4728 & 0.5006 & 0 & 1 \\
Information (I) & 184 & 0.7934 & 0.4059 & 0 & 1 \\
RO brand (RoB) & 184 & 0.8423 & 0.3653 & 0 & 1 \\
Market share (MS) & 184 & 0.4574 & 2.038 & 0.05 & 26.98 \\
\hline Source: Authors' work & & & &
\end{tabular}

Source: Authors' work.

The other characteristics of the studied companies show that their age varies from 2 years to 28 years in the marker, with an average of 10.6 years. Their number of employees 
also diversified, from one employee to 10,769 employees, but on average, the companies have 416.3 employees. Of the companies, $84 \%$ were Romanian brands and $47 \%$ had a physical store and an online one.

The correlations between all the indicators are presented in Table 4. The endogenous variable, recognize brand, shows a positive and significant correlation with age, employees, market share, and physical stores, and a significant negative correlation with ROE, ROA, $\mathrm{RO}$ brand, and the e-commerce category.

Table 4. Correlation matrix.

\begin{tabular}{|c|c|c|c|c|c|c|c|c|c|c|c|c|}
\hline & ROE & ROA & NPM & RB & A & $E$ & GR & EC & $\mathrm{S}$ & I & B & MS \\
\hline ROE & 1 & & & & & & & & & & & \\
\hline ROA & $0.636^{* * *}$ & 1 & & & & & & & & & & \\
\hline NPM & $0.336^{* * *}$ & $0.705^{* * *}$ & 1 & & & & & & & & & \\
\hline $\mathrm{RB}$ & $-0.152 * *$ & $-0.131^{* *}$ & -0.078 & 1 & & & & & & & & \\
\hline A & $-0.182 * *$ & $-0.178^{* *}$ & -0.032 & $0.449^{* * *}$ & 1 & & & & & & & \\
\hline E & $-0.237^{* * *}$ & $-0.166^{* *}$ & -0.084 & $0.361^{* * *}$ & $0.363^{* * *}$ & 1 & & & & & & \\
\hline GR & 0.107 & 0.128 * & 0.004 & 0.001 & 0.001 & 0.080 & 1 & & & & & \\
\hline $\mathrm{EC}$ & -0.041 & -0.028 & -0.035 & $-0.146^{* *}$ & $-0.146^{* *}$ & 0.064 & 0.043 & 1 & & & & \\
\hline$S$ & $-0.178^{* *}$ & $-0.234^{* * *}$ & -0.064 & $0.370^{* * *}$ & $0.370^{* * *}$ & $0.259^{* * *}$ & -0.001 & 0.021 & 1 & & & \\
\hline I & $-0.173^{* *}$ & $-0.241^{* * *}$ & -0.117 & $0.264^{* * *}$ & $0.264^{* * *}$ & 0.134 * & -0.001 & -0.029 & $0.187^{* *}$ & 1 & & \\
\hline B & 0.185 & 0.090 & 0.006 & $-0.554^{* * *}$ & $-0.554^{* * *}$ & $-0.307^{* * *}$ & -0.115 & -0.036 & $-0.36^{* * *}$ & $-0.18 * *$ & 1 & \\
\hline MS & $-0.127^{*}$ & -0.112 & -0.103 & $0.190 * * *$ & $0.147^{* *}$ & $0.240^{* * *}$ & -0.059 & -0.116 & 0.110 & 0.058 & -0.002 & 1 \\
\hline
\end{tabular}

The financial indicator return of equity had a positive and statistically significant correlation with return on assets, net profit margin and ranks, and a negative significant correlation with recognized brand, age of the company, number of employees, the existence of physical stores, information, and market share. Return on assets had a strong positive correlation with NPM and a significant negative correlation with: RB, age, employees, physical stores, and information.

The econometric analysis started with simple linear regression, and we obtained that R-squared was 0.65 , which means that there is a strong significant link between the variables. The modification of the independent variables can influence $65 \%$ the modification of the dependent variable, recognized brand. The ANOVA test revealed that F (6.178) was 55.82 at $1 \%$ level of significance, higher than the critical level; therefore the model is valid. The results of the Doornik-Hansen test rejected the null hypothesis of multivariate normality (Chi2(14) $=19,004.2$ with $p$-value of 0.0000$)$ and the Lawley test rejected the null hypothesis that the correlation matrix is compound symmetric (Chi2(20) $=151.17$ with $p$-value of 0.0000) and concluded that there are probably differences in the correlations of variables. The collinearity test revealed a mean VIF of 1.09 smaller than the threshold (7), which means there were no multicollinearity issues.

Recognized brand had a significant positive correlation with physical store and information; if the company had a physical store it might increase with 0.28 the RB and if there are information about the company on their website, it might increase with 0.38 the RB. The correlation with RO brand was negative, which means that the Romanian companies have a lower chance of being ranked as RB.

The regressions results for all models can be seen in Table 5, the coefficients of correlation and with $t$ values from the Student $t$-test, which are written in parentheses, and the significance level.

From the 2SLS regressions we obtained a Wald chi2 bigger than the threshold at a $99 \%$ confidence level for all models, which shows that the models are statistically significant. Additionally, the mean VIF was 2.03 smaller than the threshold, which means there were no multicollinearity issues.

Afterwards, we used Durbin-Wu-Hausman tests to check if RB was an endogenous variable, and we obtained $p$-values of 0.000 , rejecting the null hypothesis that the variable is exogenous. We checked for weak instruments by performing the first-stage regression and obtained a partial R-squared of 0.26 , and the minimum eigenvalue statistic was 32.77 higher than all the critical levels. Therefore, we reject the null hypothesis that the instruments are weak. 
Table 5. Results of regressions.

\begin{tabular}{|c|c|c|c|c|}
\hline \multirow{2}{*}{ Variables } & DV: RB & DV: ROE & DV: ROA & DV: NPM \\
\hline & (OLS) & (2SLS) & (2SLS) & (2SLS) \\
\hline R-squared & 0.52 & & & \\
\hline F (3.181) & $32.77^{* * *}$ & & & \\
\hline Wald chi2 (3) & & $21.76^{* * *}$ & $15.88^{* * *}$ & $7.26^{* *}$ \\
\hline $\mathrm{A}$ & & $1.67(2.30) * * *$ & $0.64(1.90)^{* * *}$ & $0.314(2.89)^{* * *}$ \\
\hline $\mathrm{E}$ & & $20.29(5.48)^{* * *}$ & $8.77(5.09)^{* * *}$ & $0.314(2.89)^{* * *}$ \\
\hline $\mathrm{RB}$ & & $-132.25(-5.79)^{* * *}$ & $-58.81(-5.35)^{* * *}$ & $-15.90(-4.67)^{* * *}$ \\
\hline \multicolumn{5}{|l|}{ Instruments } \\
\hline GR & $0.006(1.32)$ & & & \\
\hline $\mathrm{EC}$ & $0.017(0.85)$ & & & \\
\hline$S$ & $0.285(4.53)^{* * *}$ & & & \\
\hline I & $0.385(5.68)^{* * *}$ & & & \\
\hline B & $-0.247(-3.80)^{* * *}$ & & & \\
\hline MS & $0.038(2.53) * *$ & & & \\
\hline Mean VIF & 1.09 & 2.03 & 2.03 & 2.03 \\
\hline Durbin (score) chi2 (1) & & $60.05^{* * *}$ & $45.17^{* * *}$ & $25.39 * * *$ \\
\hline Wu-Hausman F $(1,180)$ & & $87.22 * * *$ & $58.58^{* * *}$ & $28.82 * * *$ \\
\hline Sargan (score) chi2 (5) & & 8.43 & 7.21 & 5.00 \\
\hline Basmann chi2 (5) & & 8.45 & 7.18 & 4.91 \\
\hline
\end{tabular}

$\mathrm{t}$ values are reported in parenthesis; and ${ }^{* *}$ and ${ }^{* * *}$ mean $10 \%, 5 \%$ and $1 \%$ level of significance. Source: Authors' work using Stata 14 software.

Testing for overidentification, we obtained a high level of p-value for Sargan and Basmann tests, and we accept the null hypothesis that the instrument set is valid, and the model is correctly specified.

The regression results show that overall, RB has a significant negative influence on the financial performance. If it is a RB company the return on equity might be lower by $132 \%$, return on assets might be lower by $58 \%$, and net profit margin might be lower by $15.9 \%$ compared to the non-RB companies. The independent variables, age and number of employees have a positive impact on the financial performance of the companies.

\section{Discussions}

From the quantitative analysis of the characteristics of the companies, the relationship between brand recognition and financial performance was validated. This topic was also studied in previous research $[31,36,37]$ with different outcomes. Even if there is a strong brand recognition, profitability may be low due to IT systems, market conditions or marketing programs' inefficiency. However, brand recognition is of strategic importance, even if it is not the only factor influencing the company's performance.

Previous research has shown a positive association between brand equity and measuring the market value and performance of listed companies and strong brands worldwide. Our results indicate that non-RB firms have had stronger financial performance, in line with Schmitz and Roman [36], who studied unlisted SMEs.

The data analysis on the two groups showed that the maximum values of ROE, ROA, and NPM were found in non-RB companies, which also influenced the regression results. The justification for these high values is that these companies have a low share capital, they do not have substantial investments in their companies, and thus the profit obtained positively influences the profitability ratios.

The study results showed that the relationship between RB and market share was statistically significant, according to the study of Zarantonello et al. [33] that show that in emerging countries, like Romania, the relationship between each CBBE component and market share was stronger for global brands than local ones.

Our study contributes to the previous literature on the relevant dimensions of ecommerce. The purpose of the companies is to ensure a high return on shareholders. The result supports a growing literature that addresses the link between brand equity 
and financial performance. Moreover, most previous studies were conducted in Western Europe and brand equity has played a more significant role in Western cultures than in Eastern cultures [66]. The results obtained are added to previous studies in the case of Romania [45,67] and other Eastern European countries [68,69].

Even though we expected a positive relationship between recognized brand and financial performance, the results showed a negative one. The results are solid to include several instrumental variables and alternative definitions of financial performance, and the relations are the same with all financial performance indicators analyzed.

Based on the estimates of specialized organizations [9], online commerce increased in Romania by over 20\% in 2019 compared to 2018; in our sample, the increase is even higher, by $34 \%$. E-commerce has not been affected by the pandemic crisis, the most affected being non-food retailers. To meet the challenges, they have accelerated the digitalization of business. Euromonitor International [70] estimated an increase in the Romanian ecommerce market in 2020 by $32 \%$ and, as a result, the share of e-commerce in the total retail trade is $10 \%$ of the total. In these unprecedented circumstances, with an increase in online sales and a decrease in final consumer spending, there is a strict general need to move companies to the online environment for them to remain competitive in the market.

The results of this study have managerial implications for short-term and long-term strategies. In the short term, managers can create strategies to improve customer relationships by revealing more information about the company [47], the products they sell online and the company's sustainability actions. In the long term, increasing e-commerce sales volume is a challenge that requires a rapid adaptation of sales strategies and a rethinking of logistics of the supply chain to meet consumers' needs. Thus, to survive in the market long-term, lesser-known companies have to invest more in building brand recognition. Even if this investment does not bring them immediate profits, it represents an opportunity for the future to strengthen the trust in the company and for sustainable competitiveness.

Considering new challenges deriving from e-commerce market trends, companies have to confront increasing competition through social networks. Managers have to develop new business scenarios to capture content extraction and analysis opportunities to calibrate roadmaps toward brand consolidation.

\section{Conclusions}

This paper presented the characteristics of the e-commerce market in Romania on a sample of companies based in Romania with revenues of more than EUR 1 million in 2019 and with at least two years of experience. The data analysis showed significant differences between the two groups of companies in the case of all the analyzed indicators, which shows that brand equity is an essential factor for gaining a position in the e-commerce market for sustainable competitiveness. In the paper, information was compiled from several sources. Two-stage least squares (2SLS) regression was used to control a set of instrumental variables that may influence brand equity to reduce the potential for endogenous bias.

Most of the research has investigated the benefits of brand equity from a cognitive psychology perspective $[37,54,57]$ but this research focuses on the available data from the e-commerce industry database. The results from the econometric models showed that the non-RB companies registered higher values of return on equity, return on assets, and net profit margin. In the context studied in this paper, we highlighted that brand recognition and financial performance influence each other and for the company to improve the customer relationship, they have to invest in brand consolidation. Promoting sustainability actions can help the customers to understand the need to protect the environment [71] in line with the concerns of European e-commerce associations [72].

The paper can be a bibliographic source for researchers in e-commerce and financial analysis, both through the indicators used, especially the instrumental variables, and the econometric model tested. 
Our study presented some limitations that indicate the potential of future research. First, the results are limited to the chosen sample on a single e-commerce market and the analyzed period, but we considered it relevant for this topic. Due to the characteristics of the sample, the results did not confirm the initial expectations, respectively, that brand equity should positively influence financial performance. The second limitation is that the companies' governance indicators associated with financial performance were not included due to the characteristics of the sample, which included small companies with at least one employee to large companies with over 10,000 employees. Although our study empirically supported the link between brand recognition and financial performance, not all the instrumental variables were statistically validated.

Future research directions can be oriented to study the relationship of brand recognition with financial performance in the long term and can be extended by comparative analyses on several e-commerce markets with the inclusion of other relevant variables.

Author Contributions: Conceptualization, C.-D.H., R.-I.P., V.-P.H. and C.M.I.; data curation, R.-I.P.; formal analysis, R.-I.P.; investigation, C.-D.H. and C.M.I.; methodology, C.-D.H.; R.-I.P. and V.-P.H. Project administration, C.-D.H.; resources, C.-D.H. and R.-I.P.; software, R.-I.P., supervision, C.-D.H. and R.-I.P.; validation, R.-I.P.; visualization, C.-D.H.; writing—original draft, C.-D.H., R.-I.P., V.-P.H. and C.M.I.; writing-review \& editing, C.-D.H. All authors have read and agreed to the published version of the manuscript.

Funding: The funding information is This article was funded through the FDI-2021-0414 project"Developing the institutional capacity of the West University of Timisoara regarding excellence in scientific research".

Institutional Review Board Statement: Not applicable.

Informed Consent Statement: Not applicable.

Data Availability Statement: Data supporting reported results are not publicly archived.

Acknowledgments: We would like to thank the reviewers and editors for the recommendations made to improve the paper.

Conflicts of Interest: The authors declare no conflict of interest.

\section{References}

1. EUROSTAT. E-Commerce Statistics. Available online: https:/ / ec.europa.eu/eurostat/statistics-explained/index.php?title=Ecommerce_statistics_for_individuals\#E-shopping_from_other_EU_countries (accessed on 15 August 2021).

2. Statista. Cashless Society in Europe: A Winding Road. Available online: https://www.statista.com/study/79347/cashlesssociety-in-europe-a-winding-road/ (accessed on 18 August 2021).

3. Tasci, A.D. A critical review and reconstruction of perceptual brand equity. Int. J. Contemp. Hosp. Manag. 2020, 33, 166-198. [CrossRef]

4. Kim, H.-B.; Kim, W.G.; An, A. The effect of consumer-based brand equity on firms' financial performance. J. Consum. Mark. 2003, 20, 335-351. [CrossRef]

5. Aaker, D.A. Managing Brand Equity; The Free Press: New York, NY, USA, 1991.

6. Aaker, D.A. Building Strong Brands; The Free Press: New York, NY, USA, 1996.

7. Keller, K.L. Conceptualizing, measuring, and managing customer-based brand equity. J. Mark. 1993, 57, 1-22. [CrossRef]

8. Keller, K.L.; Lehmann, D.R. Brands and branding: Research findings and future priorities. Mark. Sci. 2006, 25, 740-759. [CrossRef]

9. ARMO (Romanian Association of Online Stores). E-Commerce Romania 2019. Available online: https://www.gpec.ro/blog/ raport-gpec-e-commerce-romania-2019 (accessed on 25 August 2021).

10. Wittgenstein, L. Tractatus Logico-Philosophicus; Routledge: London, UK, 1994.

11. Marga, A. Introducere în Filosofia Contemporană; Compania Publishing House: București, Romania, 2014; pp. 280, 299 , 301.

12. Wittgenstein, L. Culture and Value, 2nd ed.; Blackwell: Oxford, UK, 1998.

13. Dinu, G. Religia Comunicării. Manipularea Mistică a Consumatorului \& Noua Filocalie; Integral: București, Romania, $2019 ;$ p. 69.

14. Austin, J.L. How to Do Things with Words; Oxford University Press: Oxford, UK, 1975; Volume 88.

15. Searle, J. Speech Acts. An Essay in the Philosophy of Language; Cambridge University Press: Cambridge, MA, USA, 1969.

16. Escobar, A. Designs for the Pluriverse: Radical Interdependence, Autonomy, and the Making of Worlds; Duke University Press: Durcham, NC, USA, 2018.

17. Popa, S.; Soto-Acosta, P.; Perez-Gonzalez, D. An investigation of the effect of electronic business on financial performance of Spanish manufacturing SMEs. Technol. Forecast. Soc. Chang. 2018, 136, 355-362. [CrossRef] 
18. Šaković Jovanović, J.; Vujadinović, R.; Mitreva, E.; Fragassa, C.; Vujović, A. The Relationship between E-Commerce and Firm Performance: The Mediating Role of Internet Sales Channels. Sustainability 2020, 12, 6993. [CrossRef]

19. Sedighi, A.; Sirang, B.; Azerbaijan, I. The effect of e-commerce on SME Performance. Int. J. Appl. Res. Manag. Econ. 2018, 1, 71-81.

20. Orzan, M.C.; Burlacu, S.; Florescu, M.S.; Orzan, O.A.; Macovei, O.I. The effects of online marketing on financial performance in the textile industry. Ind. Text. 2020, 71, 288-293. [CrossRef]

21. Christodoulides, G.; De Chernatony, L. Consumer-based brand equity conceptualisation and measurement: A literature review. Int. J. Mark. Res. 2010, 52, 43-66. [CrossRef]

22. Farjam, S.; Hongyi, X. Reviewing the concept of brand equity and evaluating consumer-based brand equity (CBBE) models. Int. J. Manag. Sci. Bus. Adm. 2015, 1, 14-29. [CrossRef]

23. Clow, K.E.; Baack, D. Brand and Brand Equity; Concise Encyclopedia of Advertising; Haworth Press, Inc.: Philadelphia, PA, USA, 2005.

24. Ambler, T. Marketing and the Bottom Line; Pearson Education Limited: London, UK, 2000.

25. Kovachevski, D.; Petrovska, I.; Handjiski, V.K. Measuring Brand Performance: From Customer Based Brand Equity to Brand Financial Value. Innov. Eur. 2019, 117-130. [CrossRef]

26. Christodoulides, G.; De Chernatony, L.; Furrer, O.; Shiu, E.; Abimbola, T. Conceptualising and measuring the equity of online brands. J. Mark. Manag. 2006, 22, 799-825. [CrossRef]

27. Madden, T.J.; Fehle, F.; Fournier, S. Brands matter: An empirical demonstration of the creation of shareholder value through branding. J. Acad. Mark. Sci. 2006, 34, 224-335. [CrossRef]

28. Rego, L.L.; Billett, M.T.; Morgan, N.A. Consumer-based brand equity and firm risk. J. Mark. 2009, 73, 47-60. [CrossRef]

29. Johansson, J.K.; Dimofte, C.V.; Mazvancheryl, S.K. The performance of global brands in the 2008 financial crisis: A test of two brand value measures. Int. J. Res. Mark. 2012, 29, 235-245. [CrossRef]

30. Larkin, Y. Brand perception, cash flow stability, and financial policy. J. Financ. Econ. 2013, 110, 232-253. [CrossRef]

31. Narteh, B. Brand equity and financial performance: The moderating role of brand likeability. Mark. Intell. Plan. 2018, 36, 381-395. [CrossRef]

32. Choi, Y.; Mai, D.Q. The sustainable role of the e-trust in the B2C e-commerce in Vietnam. Sustainability 2018, 10, 291. [CrossRef]

33. Zarantonello, L.; Grappi, S.; Formisano, M.; Brakus, J. How consumer-based brand equity relates to market share of global and local brands in developed and emerging countries. Int. Mark. Rev. 2020, 37, 345-375. [CrossRef]

34. Smith, D.J.; Gradojevic, N.; Irwin, W.S. An analysis of brand equity determinants: Gross profit, advertising, research, and development. J. Bus. Econ. Res. (JBER) 2007, 5, 103-116. [CrossRef]

35. Isberg, S.; Pitta, D. Using financial analysis to assess brand equity. J. Prod. Brand Manag. 2013, 22, 65-78. [CrossRef]

36. Schmitz, A.; Villaseñor-Román, N. Do Brands Matter in Unlisted Firms? An Empirical Study of the Association between Brand Equity and Financial Performance. Adm. Sci. 2018, 8, 65. [CrossRef]

37. Wang, H.M.D.; Sengupta, S. Stakeholder relationships, brand equity, firm performance: A resource-based perspective. J. Bus. Res. 2016, 69, 5561-5568. [CrossRef]

38. Yoon, D.; Choi, S.M.; Sohn, D. Building customer relationships in an electronic age: The role of interactivity of E-commerce Web sites. Psychol. Mark. 2008, 25, 602-618. [CrossRef]

39. Greenberg, P. The impact of CRM 2.0 on customer insight. J. Bus. Ind. Mark. 2010, 25, 410-419. [CrossRef]

40. Yen, Y.-S. Managing perceived risk for customer retention in e-commerce: The role of switching costs. Inf. Comput. Secur. 2015, 23, 145-160. [CrossRef]

41. Kim, D. Internet and SMEs' internationalization: The role of platform and website. J. Int. Manag. 2020, 26, 100690. [CrossRef]

42. Dahbi, S.; Benmoussa, C. What hinder SMEs from adopting E-commerce? A multiple case analysis. Procedia Comput. Sci. 2019, 158, 811-818. [CrossRef]

43. Jorge-Vázquez, J.; Chivite-Cebolla, M.P.; Salinas-Ramos, F. The Digitalization of the European Agri-Food Cooperative Sector. Determining Factors to Embrace Information and Communication Technologies. Agriculture 2021, 11, 514. [CrossRef]

44. Jorge-Vázquez, J.; Chivite-Cebolla, M.P.; Salinas-Ramos, F. La transformación digital en el sector cooperativo agroalimentario español: Situación y perspectivas. CIRIEC-España Rev. Econ. Pública Soc. Coop. 2019, 95, 39-70. [CrossRef]

45. Dumitriu, D.; Militaru, G.; Deselnicu, D.C.; Niculescu, A.; Popescu, M.A.M. A perspective over modern SMEs: Managing brand equity, growth and sustainability through digital marketing tools and techniques. Sustainability 2019, 11, 2111. [CrossRef]

46. Adiguzel, Z. Examination of effects of competitive strategies on the e-commerce companies in terms of achieving sustainable competitive advantage. In Tools and Techniques for Implementing International E-Trading Tactics for Competitive Advantage; IGI Global: Hershey, PA, USA, 2020; pp. 287-319.

47. Paștiu, C.A.; Oncioiu, I.; Gârdan, D.A.; Maican, S.Ș.; Gârdan, I.P.; Muntean, A.C. The perspective of e-business sustainability and website accessibility of online stores. Sustainability 2020, 12, 9780. [CrossRef]

48. Svatosova, V. The Importance of Online Shopping Behavior in the Strategic Management of E-Commerce Competitiveness. J. Compet. 2020, 12, 143. [CrossRef]

49. Oláh, J.; Kitukutha, N.; Haddad, H.; Pakurár, M.; Máté, D.; Popp, J. Achieving sustainable e-commerce in environmental, social and economic dimensions by taking possible trade-offs. Sustainability 2019, 11, 89. [CrossRef]

50. Hategan, P.V. Philosophical practice and ethics applied in organizations. An. Univ. Din București-Ser. Filos. 2019, 68, 53-65. 
51. Cheba, K.; Bąk, I.; Szopik-Depczyńska, K. Sustainable competitiveness as a new economic category-definition and measurement assessment. Technol. Econ. Dev. Econ. 2020, 26, 1399. [CrossRef]

52. Cheba, K.; Szopik-Depczyńska, K. Sustainable competitiveness and responsible innovations-The case of the European Union Countries. Res. Pap. Wroc. Univ. Econ. 2019, 549, 139-150. [CrossRef]

53. Manta, A.G.; Bădîrcea, R.M.; Pîrvu, R. The Correlation between Corporate Governance and Financial Performances in the Romanian Banks. In Current Issues in Corporate Social Responsibility; Springer: Cham, Switzerland, 2019; pp. 165-182.

54. Wang, K.; Jiang, W. Brand Equity and Firm Sustainable Performance: The Mediating Role of Analysts' Recommendations. Sustainability 2019, 11, 1086. [CrossRef]

55. Zahid, M.; Rahman, H.U.; Khan, M.; Ali, W.; Shad, F. Addressing endogeneity by proposing novel instrumental variables in the nexus of sustainability reporting and firm financial performance: A step-by-step procedure for non-experts. Bus. Strategy Environ. 2020, 29, 3086-3103. [CrossRef]

56. Yang, Z.; Shi, Y.; Yan, H. Scale, congestion, efficiency and effectiveness in e-commerce firms. Electron. Commer. Res. Appl. 2016, 20, 171-182. [CrossRef]

57. Ittner, C.D.; Larcker, D.F. Are nonfinancial measures leading indicators of financial performance? An analysis of customer satisfaction. J. Account. Res. 1998, 36, 1-34. [CrossRef]

58. Ittner, C.; Larcker, D.F.; Taylor, D. The stock market's pricing of customer satisfaction. Mark. Sci. 2009, 25, 826-835. [CrossRef]

59. De Chernatony, L. Brand management through narrowing the gap between brand identity and brand reputation. J. Mark. Manag. 1999, 15, 157-179. [CrossRef]

60. Statista. ecommerceDB.com Product Description \& Methodology. Available online: https://www.ecommercedb.com/pdf/2020 _ecommerceDB_Methodology.pdf (accessed on 10 February 2021).

61. Wooldridge, J.M. Introductory Econometrics. A modern Approach; Cengage Learning: Boston, MA, USA, 2015 ; pp. 475-479.

62. Gretz, R.T.; Malshe, A. Rejoinder to "Endogeneity bias in marketing research: Problem, causes and remedies". Ind. Mark. Manag. 2019, 77, 57-62. [CrossRef]

63. Ullah, S.; Zaefarian, G.; Ullah, F. How to use instrumental variables in addressing endogeneity? A step-by-step procedure for nonspecialists. Ind. Mark. Manag. 2020, 96, A1-A6. [CrossRef]

64. Rossi, P.E. Even the rich can make themselves poor: A critical examination of IV methods in marketing applications. Mark. Sci. 2014, 33, 655-672. [CrossRef]

65. Hategan, C.-D.; Sirghi, N.; Curea-Pitorac, R.-I. The financial indicators influencing the market value of the Romanian listed companies at the regional level. In Economic and Social Development: Book of Proceedings; Varazdin Development and Entrepreneurship Agency: Varazdin, Croatia, 2017; pp. 160-171.

66. Zhang, S.S.; van Doorn, J.; Leeflang, P.S. Does the importance of value, brand and relationship equity for customer loyalty differ between Eastern and Western cultures? Int. Bus. Rev. 2014, 23, 284-292. [CrossRef]

67. Moisescu, O.I. The importance of brand awareness in consumers'buying decision and perceived risk assessment. Manag. Mark. J. 2009, 1, 103-110.

68. Grebosz-Krawczyk, M. The impact of nostalgia on the brand equity in economy with post-communist background. Econ. Sociol. 2018, 11, 216-228. [CrossRef]

69. Štarchoň, P.; Weberová, D. Spontaneous Brand Awareness and Consumer Attitudes to Brands in the Czech Republic and Slovakia. In Proceedings of the International Conference on Strategic Innovative Marketing, Pafos, Cyprus, 2017; Springer: Cham, Switzerland, 2017; pp. 151-158.

70. Euromonitor International. E-Commerce in Romania. Available online: https://www.euromonitor.com/e-commerce-inromania/report (accessed on 25 August 2021).

71. Hategan, V.-P. Promoting the Eco-Dialogue through Eco-Philosophy for Community. Sustainability 2021, 13, 4291. [CrossRef]

72. Ecommerce Europe. Collaborative Report on Sustainability and e-Commerce 2020. Available online: https://www.ecommerceeurope.eu/wp-content/uploads/2020/09/Collaborative-Report-on-Sustainability-and-e-Commerce.pdf (accessed on 25 August 2021). 